\title{
Takeover Law Regulations and Their Influence on the Takeover Premium - An Empirical Study of the OECD Member States
}

\author{
DOI 10.18267/pr.2021.krn.4816.14
}

\author{
Jan-Hendrik Meier ${ }^{1}$ - Tetiana Paientko ${ }^{2}$ - Kristina Reschke ${ }^{3}$ \\ ORCID iD: 0000-0002-3080-22101, 0000-0002-2962-308X², not available ${ }^{3}$ \\ jan-hendrik.meier@fh-kiel.de, tpayentko@kneu.edu.ua \\ ${ }^{1,3}$ Kiel University of Applied Sciences, Business School, Institute of Auditing and \\ Accounting \\ Kiel, Germany \\ ${ }^{2}$ Kyiv National Economic University named after Vadym Hetman, Department of \\ Finance \\ Kyiv, Ukraine
}

\begin{abstract}
Almost all OECD and G20 countries have introduced a mandatory bid rule (MBR) in conjunction with a fair price regulation in their national takeover laws. MBRs require that a takeover bid must be made to all shareholders, if a certain control threshold is being exceeded. We show that takeovers that exceed such a threshold are associated with below-average takeover premiums. Other national characteristics of the MBR also show significant influences on the takeover premium. In addition, significantly higher premiums are paid when the buyer is seeking for between $20 \%$ and $40 \%$ of the shares after the takeover.
\end{abstract}

Keywords: merger \& acquisitions, mandatory bid rule, fair price regulation

JEL Classification codes: G18

\section{INTRODUCTION}

The legislator has an interest in protecting minority shareholders and thus controlling the M\&A market. With the Takeover Directive 2004/25/EC, the European legislator introduced a Mandatory Bid Rule (MBR) based on the concept originally derived from the City Code on Takeovers and Mergers in the UK. MBRs require that a takeover bid must be made to all shareholders if certain control thresholds are exceeded. The amount and number of these thresholds is at the discretion of the respective states. In combination with fair-price rules, MBRs are designed to ensure the rights of minority shareholders to potential premium offers. Almost all OECD and G20 countries have now introduced such regulations.

Pérez-Soba et. al. (2017) examine the bidding behavior in the Spanish market for partial control below the MBR. They distinguish primarily between those block transactions that result in obtaining a seat on the board or governing body from those transactions that do not. Or in other words, they distinguish between transactions that grant the opportunity for certain control and those that represent a mere financial investment. The authors could not find significant differences in premiums for both types of transactions. Nevertheless, if differentiated between those acquirers who have not yet gained any control over the company and those who already have a certain control, the former are willing to pay a significantly higher premium than the latter. In other words, crossing specific control thresholds has a specific value for the acquirers for which they are willing to pay a higher premium. 
Using the difference-in-difference approach (DiD), Eswar (2019) is able to show that target values in terms if target-CARs increase for transactions crossing the MBR after the MBR was implemented by the respective legislation. Further, the author analyzes different value creation channels to research why the implementation of an MBR creates value for the target shareholders. Among other value creation channels, Eswar tests the overpayment or value transfer hypothesis. This channel postulates that values are transferred from the acquirer to the target. To test this hypothesis, the author applies the acquirer-CARs, but finds no significant value transfer. This is surprising in two ways: First, the author does not really include the overpayment in his analysis, since the premium is not recognized as an explaining variable. Instead, the author measures the capital market reaction, which is influenced by the premium itself. And second, the non-significance contradicts a large body of literature that repeatedly points to agency conflicts that could tempt the buyer's management to act against the interests of its own shareholders and should, as a consequence, reduce acquirer's value (e.g., Bruner, 2002, Martynova \& Renneboog, 2008, Jensen \& Ruback 1983, Andrade, Mitchell \& Stafford, 2001, and Betton, Eckbo \& Thorburn, 2008).

Even without an MBR, different takeover premiums would have to result for exceeding certain control thresholds. However, this behavior has only been studied below the MBR threshold by Pérez-Soba et. al. (2017) and far above the threshold by a number of earlier papers indicating the existence of control premiums (Zhu and Jog 2009, Damodaran 2005). Thus, the introduction of the MBR must have an effect on the acquirer's behavior, since the acquirers are now obliged to make a tender offer to all outstanding shareholders - possibly with the consequence of having to acquire further shares and gaining further control. The impact of the MBRs on the size of the takeover premium is, thus, currently understudied.

Our analysis shows significantly lower acquisitions premiums in deals exceeding the MBR threshold. Accordingly, we contribute a first time analysis of the impact of these rules to the acquirer's willingness to pay in a corporate takeover. In addition, in this analysis we control for the influence of the existing control over the target firm on the premium and the level of control achieved during the transaction. These aspects have been considered since the existence of a control premium has been demonstrated (Zhu and Jog 2009, Damodaran 2005).

Filling this research gap is relevant for advising companies considering a transaction that would result in the MBR threshold being exceeded. But the results can also be helpful and informative in the strategy process before any transaction is initiated and in the selection of a potential target. Furthermore, the present analysis is of interest to European and national legislators whose legislation should be subjected to an effectiveness review.

We contribute to the literature by analyzing for the first-time acquirer's behavior when the MBR threshold is exceeded. We are also the first to investigate to what extent the successive acquisition of control affects the takeover premiums offered.

The remainder of the paper is structured as follows. After the literature review, Section 2 shows the methodology and sample applied in this analysis. Section 3 shows the results, and section 4 concludes the paper.

\section{LITERATURE REVIEW}

The determinants of acquisition premiums in different markets have been a well-researched topic in recent decades. The following table summarizes the key findings. The variables in italics are later included as controls in the model. 
Tab. 1 Literature and Variable Table

\begin{tabular}{|c|c|c|}
\hline & Findings in the extant literature & References: \\
\hline $\begin{array}{l}\text { Acquisition of } \\
\text { Control } \\
(\text { MOCKTHxx) }\end{array}$ & $\begin{array}{l}\text { The premiums for gaining controlling majorities } \\
\text { are significantly higher in comparison to minority } \\
\text { interests. Various studies show a positive } \\
\text { correlation between the gaining of a controlling } \\
\text { majority and the takeover premium. }\end{array}$ & $\begin{array}{l}\text { Ouimet (2013); Zhu and Jog } \\
\text { (2009); Williamson (1971); } \\
\text { Williamson (1983); } \\
\text { Williamson, Wachter \& Harris } \\
\text { (1975); Teece (1980) }\end{array}$ \\
\hline $\begin{array}{l}\text { Considerat. } \\
\text { Structure } \\
\text { (CONCASH) } \\
\text { (CONSTOCK) }\end{array}$ & $\begin{array}{l}\text { Transactions financed with cash gain higher } \\
\text { premiums than stock swaps. }\end{array}$ & $\begin{array}{l}\text { Dombret (2002); Wansley, } \\
\text { Lane and Yang (1983); } \\
\text { Davidson and Cheng (1997); } \\
\text { Goergen and Renneboog } \\
\text { (2004); Wansley, Lane and } \\
\text { Yang (1987); Davidson and } \\
\text { Cheng's (1997); Stulz (1988); } \\
\text { Amihud, Lev and Travlos } \\
\text { (1990); Ghosh and Ruland } \\
\text { (1998) }\end{array}$ \\
\hline $\begin{array}{l}\text { Deal Attitude } \\
\text { (ATTHOST) } \\
\text { (ATTNEUT) }\end{array}$ & $\begin{array}{l}\text { Due to higher competition between the bidders } \\
\text { the level of the premium of hostile takeovers is } \\
\text { higher than of friendly ones. The premiums for } \\
\text { companies that use measures to defend against } \\
\text { hostile takeovers like poison pills and golden } \\
\text { parachutes are higher than for those targets that } \\
\text { do not protect themselves against hostile } \\
\text { takeovers. }\end{array}$ & $\begin{array}{l}\text { Franks and Mayer (1996); } \\
\text { Jensen (1988); Goergen and } \\
\text { Renneboog (2004); Varaiya } \\
\text { (1987); Flanagan and } \\
\text { O'Shaugnessy (2003) }\end{array}$ \\
\hline $\begin{array}{l}\text { Public Status } \\
\text { (ACQPUS) }\end{array}$ & $\begin{array}{l}\text { Private acquirers pay significantly lower } \\
\text { premiums than public ones, which could be due } \\
\text { to different ownership structures. The ownership } \\
\text { of private companies is higher concentrated than } \\
\text { of public ones. }\end{array}$ & $\begin{array}{l}\text { Demsetz and Lehn (1985); } \\
\text { Alexandridis (2013); Zhu and } \\
\text { Jog (2009) }\end{array}$ \\
\hline $\begin{array}{l}\text { Industry } \\
\text { (ACQIND) } \\
\text { (TARIND) }\end{array}$ & $\begin{array}{l}\text { The impact of the acquirers or targets industry } \\
\text { on the acquisition premia is controversial. Some } \\
\text { authors show in their studies significant } \\
\text { differences in premiums between industries, and } \\
\text { that intra-industry transactions are associated } \\
\text { with higher premiums while others find no } \\
\text { statistical evidence for these phenomena }\end{array}$ & $\begin{array}{l}\text { Dutz (1989); Cakici, Hessel } \\
\text { and Tandon (1991); Gaspar, } \\
\text { Massa and Matos (2005); } \\
\text { Alexandridis (2013); Zhu and } \\
\text { Jog (2009) }\end{array}$ \\
\hline $\begin{array}{l}\text { Timing } \\
\text { (YEARxxxx) }\end{array}$ & $\begin{array}{l}\text { Merger and acquisition activity can be seen as a } \\
\text { wave phenomenon over time. The different } \\
\text { waves are triggered by e.g. macroeconomic } \\
\text { factors, economic shocks, overvaluation of } \\
\text { acquiring companies, and risk management } \\
\text { through vertical integration. Prior exogenous } \\
\text { shocks can trigger envious CEOs to acquire or } \\
\text { merge with other companies, which can cause a } \\
\text { wave effect. }\end{array}$ & $\begin{array}{l}\text { Meier, Boysen-Hofgrefe \& } \\
\text { Spoida (2017); Lambrecht } \\
\text { (2004); Schleifer \& Vishny } \\
\text { (2003); Rhodes-Kropf, } \\
\text { Robinson and Vishwanathan } \\
\text { (2005);Cai and Vijh (2007); } \\
\text { Mitchell and Mulherin } \\
\text { (1996);Garfinkel and Hankins } \\
\text { (2011); Ovtchinnikov (2010); } \\
\text { Goel and Thako (2010) }\end{array}$ \\
\hline
\end{tabular}




\begin{tabular}{|c|c|c|}
\hline $\begin{array}{l}\text { Deal Value } \\
\text { (In_DEAVAL) }\end{array}$ & $\begin{array}{l}\text { In the acquisition process there are often few } \\
\text { competitors on the acquirer's side when the } \\
\text { target is a large company, who has often a high } \\
\text { concentration of owners. The recent literature } \\
\text { produced mixed findings, while some authors } \\
\text { show that large deal volumes lead to a lower } \\
\text { premium, others find a positive correlation } \\
\text { between the level of premiums and the } \\
\text { transaction size }\end{array}$ & $\begin{array}{l}\text { Alexandridis et al. (2013); } \\
\text { Demsetz \& Lehn (1985); } \\
\text { Bauguess, Moeller, } \\
\text { Schlingemann \& Zutter } \\
\text { (2009); Moeller, } \\
\text { Schlingemann and Stulz } \\
\text { (2004); Morck, Shleifer and } \\
\text { Vishny (1990); Grinstein and } \\
\text { Hribar (2004); Herford and Li } \\
\text { (2007); Zhu and Jog (2009) }\end{array}$ \\
\hline Legislation & $\begin{array}{l}\text { In domestic transactions, good shareholder } \\
\text { protection leads to more M\&A activity and } \\
\text { subsequently to higher premiums. Accordingly, is } \\
\text { the ownership concentration in states with low } \\
\text { shareholder protection high, and thus M\&A } \\
\text { activity is low. For cross-border transactions it } \\
\text { can be shown that acquirers have usually better } \\
\text { shareholder protection and accounting standards } \\
\text { than the targets which leads to a shift in the } \\
\text { corporate governance system towards better } \\
\text { protection. Various studies found that the } \\
\text { premium paid is dependent on the target nation, } \\
\text { ownership concentration, development of the } \\
\text { capital market, and experience in the target } \\
\text { market. }\end{array}$ & $\begin{array}{l}\text { Levine (2002); Rossi and } \\
\text { Volpin (2004); La Porta et. Al. } \\
\text { (1997,1998); Dyck and } \\
\text { Zingales (2004); Goergen and } \\
\text { Renneboog (2004); Zhu and } \\
\text { Jog (2009); Zhu and Jog } \\
\text { (2011) }\end{array}$ \\
\hline
\end{tabular}

\section{METHODOLOGY}

The present study is based on those 46,032 transactions that were recorded for the period between January 2013 and December 2019 in the Refinitiv Eikon Dealscreener database. Transactions with a volume of less than USD 1 million were excluded in order to eliminate small deals from the sample due to their economic insignificance. Furthermore, only transactions where the target is listed could be considered. In combination with information on national MBR regimes from the OECD Corporate Governance Factbook (OECD 2014, 2015, 2017, 2019), 11,244 complete observations remained in the sample. As a result, only targets from the 42 OECD, G20, and Financial Stability Board member nations were included in the sample. After removal of small deals, deals without public takeover offer, deals outside OECD and deals with missing data, 11,244 deals remained in the sample.

In line with the extant literature (e.g. Antoniou, Arbour, and Zhao (2008)), the offered premium (PREM4W) for the purpose of this analysis is defined as the ratio between the offered price per share and the closing price four weeks before the announcement of the offer. To test the robustness of the model, the 1-week and 1-day premiums were also examined (not tabulated). In the latter two cases, it becomes more and more likely that information about the deal has already been leaked and is thus already integrated into the market price. Accordingly, the share price in these cases should already incorporate the information about the takeover, which means in most cases a dilution of the premium.

To test our hypothesis and to analyze the effect of exceeding the threshold in terms of the national MBR, a dummy (EXCEEDTH) is applied to the transactions that exceed the threshold. Additionally, mock thresholds were created to reflect the effect of increasing control over the target. For this purpose, nine dummy variables were created to represent the increase in control in $10 \%$ increments. MOCK10, shows transactions where the acquirer holds less than 
$10 \%$ of the target's shares beforehand and $10 \%$ or more thereafter. MOCK20 through MOCK90 are analogous.

The different aspects of the mandatory bid rules were represented by the following variables: the six levels of thresholds (MINTH) due to the according national MBR, a dummy for the presence of multiple thresholds (MULTITH), and a dummy variable for an ex post approach (EXPOST), in which a takeover bid must be made after the transaction in which the threshold was exceeded has been completed. In contrast to the latter, the an ex ante approach states that a takeover bid must be made before the transaction in which the threshold is crossed is completed.

The control variables for the consideration structure are CONCASH for a cash payment and CONSTOCK for a stock swap. These are reflected against a mixed payment. The deal attitude differentiates between a hostile takeover (ATTHOST) and a neutral takeover (ATTNEUT). Both are reflected against a friendly takeover. The acquirer public status is differentiated by private company (ACQPSPR) and other (ACQPSOT), both reflected against public as a benchmark. The public status of the target is always public in public offers. The industry affiliation of the acquirer (ACQIND) and the target (TARIND) is in all cases reflected against consumer cyclicals and services. To include the size of completed transactions the deal volume is logarithmized (In_DEALVAL).

Heteroskedasticity is assumed in the data set, therefore heteroskedasticity robust standard errors are applied in the following ordinary least squares (OLS) regression (White, 1980/Huber, 1967):

$$
\begin{aligned}
\text { PREM }_{4}= & \text { const }_{i}+\text { EXCEEDTH }_{i}+\text { EXPOST }_{i}+\text { MULTITH }_{i}+ \\
& \sum_{a} \text { MINTH }_{a, i}+\sum_{b} \text { MOCKTH }_{b, i}+\text { CONTROLS }_{+} \varepsilon_{i}
\end{aligned}
$$

In Model (2) we further differentiate the interaction effects of exceeding the threshold with the ex-post approach, with the respective minimum threshold and with the multi-threshold approach.

\section{RESULTS AND DISCUSSION}

The acquirers/targets belong to the following sectors: Cyclical Consumer Goods and Services $(678 / 2,310)$, Basic Materials (522/1,368), Energy (240/408), Financials $(5,982 / 1,644)$, Government Services (198/0), Healthcare (168/594), Industrials (1. 122/2,352), consumer non-cyclical goods and services (336/870), technology $(378 / 1,140)$, telecom services (114/246), utilities (234/312), and unknown (1,272/0).

Of the 11,244 transactions, 7,878 were fully funded with cash, 402 were equity swaps, and the settlement of the remaining 2,964 transactions was mixed or unknown. 9,186 acquisitions were friendly, 48 were documented as hostile. Neutral or unknown were 2,010 takeovers.

A minimum threshold of $20 \%$ for the nation of the target is present in 654 transactions, and a minimum threshold of $25 \%$ is present in 1,698 transactions. A $30 \%$ threshold is present in 6,216 transactions, and $33 \%$ in 1,764 . In 756 transactions, the threshold is $50 \%$, and in 84 transactions, the threshold is $67 \%$. In the remaining 72 cases, there is no threshold at which a takeover bid must be made. In 2,286 transactions, a threshold was exceeded. 8,958 transactions took place above or below it. In 9,174 transactions, the MBR follows the ex-post approach; in the remaining 2,070 transactions, the ex-ante approach is used. Multiple thresholds are present in 5,790 transactions and one threshold in 5454 transactions.

The descriptives of the non-winsorized and non- logarithmized metric variables are presented in Table 1. 
Tab. 2 Descriptive Statistics

\begin{tabular}{lllllllll}
\hline & $\mathrm{N}$ & Mean & St. Dev. & Min & Pctl(25) & Median & Pctl(75) & Max \\
\hline PREM4W & 11,244 & 29.452 & 285.038 & -99.880 & -1.800 & 10.870 & 29.090 & $11,771.380$ \\
PREM1W & 11,244 & 26.417 & 291.018 & -99.880 & -2.100 & 8.290 & 25.410 & $12,125.110$ \\
PREM1D & 11,244 & 25.021 & 285.897 & -99.880 & -3.470 & 7.120 & 23.670 & $11,906.530$ \\
DEALVAL & 11,244 & 267.867 & $1,215.445$ & 1.010 & 9.160 & 34.828 & 128.970 & $31,879.490$ \\
\hline
\end{tabular}

The mean of the premiums deviates significantly from the median, indicating a skewed distribution of the premium, which is to be expected given the nature of these premiums. For the four-week premium, the median is $10.87 \%$, for the one-week premium it is $8.29 \%$, and for the one-day premium it is $7.12 \%$. Obviously, leaked information and rumors affect the stock price, and the unannounced premium is gradually incorporated into the price.

The distribution of the winsorized 4-week premium is shown in Figure 1 and Table 3 below shows the results of the OLS regression.

Fig. 1 Histogram of the 4-week ahead Premia

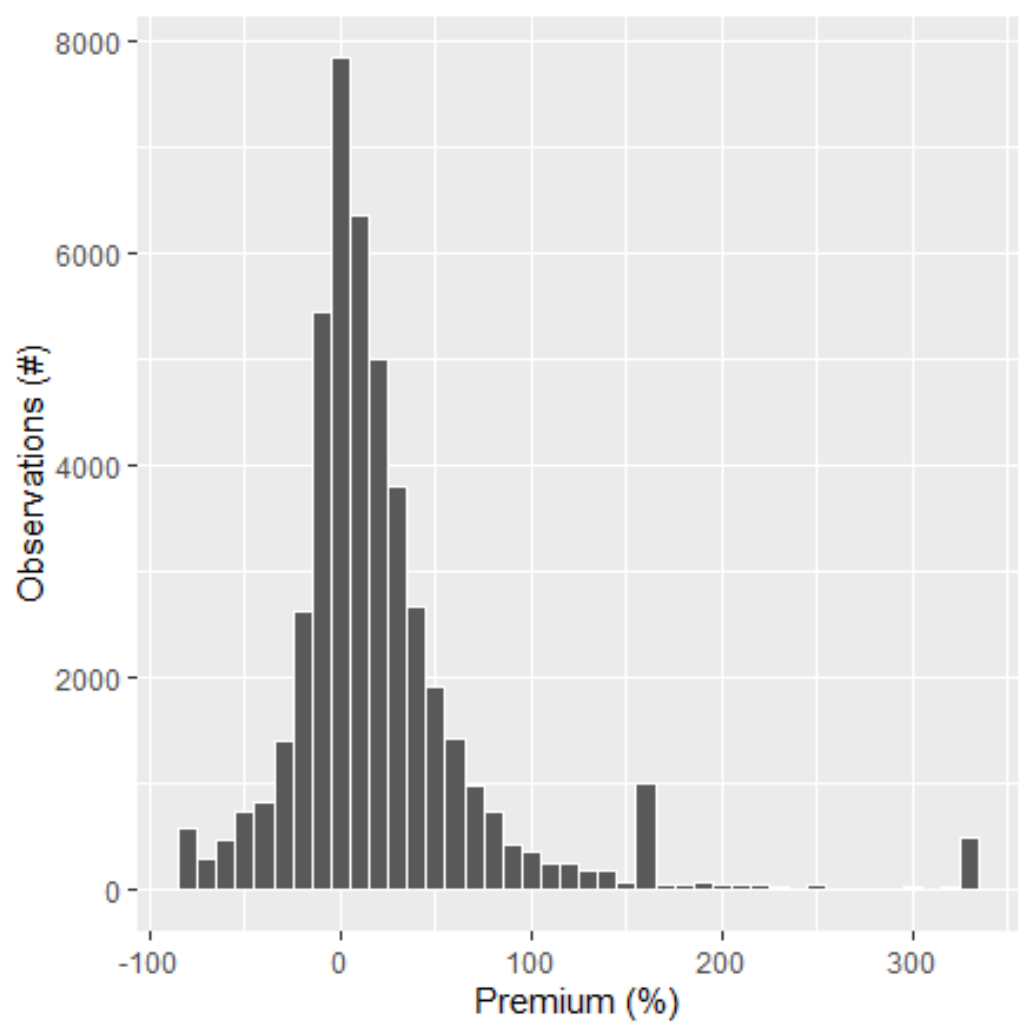


Tab. 3 Model Results

\begin{tabular}{|c|c|c|c|c|c|c|}
\hline & \multicolumn{6}{|c|}{ PREM4W } \\
\hline & \multicolumn{3}{|c|}{ (1) } & \multicolumn{3}{|c|}{ (2) } \\
\hline & Estimates & $S E$ & $p$-value & Estimates & $S E$ & $p$-value \\
\hline \multicolumn{7}{|l|}{ Mandatory Bid Rule } \\
\hline EXCEEDTH & $-25.02^{* *}$ & 8.20 & 0.002 & $-90.88^{* *}$ & 28.25 & 0.001 \\
\hline EXPOST & $-48.09^{* * *}$ & 8.95 & $<0.001$ & $-46.80^{* * *}$ & 7.89 & $<0.001$ \\
\hline MULTITH & $-27.58^{*}$ & 10.88 & 0.011 & $-32.58^{* *}$ & 11.93 & 0.006 \\
\hline $\begin{array}{l}\text { EXCEEDTH X } \\
\text { EXPOST }\end{array}$ & & & & 4.49 & 8.41 & 0.593 \\
\hline $\begin{array}{l}\text { EXCEEDTH X } \\
\text { MINTH }\end{array}$ & & & & $1.51^{*}$ & 0.59 & 0.011 \\
\hline $\begin{array}{l}\text { EXCEEDTH X } \\
\text { MMULTITH }\end{array}$ & & & & $23.57^{* *}$ & 8.79 & 0.007 \\
\hline MINTH2O & $-75.01^{* * *}$ & 10.80 & $<0.001$ & $-65.37^{* * *}$ & 9.33 & $<0.001$ \\
\hline MINTH25 & $-81.58^{* * *}$ & 10.76 & $<0.001$ & $-76.01 * * *$ & 9.24 & $<0.001$ \\
\hline MINTH30 & $-52.71^{* * *}$ & 4.73 & $<0.001$ & $-50.58^{* * *}$ & 4.35 & $<0.001$ \\
\hline MINTH33 & $-51.71^{* * *}$ & 5.87 & $<0.001$ & $-50.10^{* * *}$ & 5.58 & $<0.001$ \\
\hline MINTH50 & $-94.52^{* * *}$ & 15.46 & $<0.001$ & $-98.14^{* * *}$ & 16.67 & $<0.001$ \\
\hline MINTH67 & $-31.27^{* * *}$ & 6.75 & $<0.001$ & $-40.60^{* * *}$ & 5.89 & $<0.001$ \\
\hline \multicolumn{7}{|c|}{ Acquisition of Control } \\
\hline MOCKTH10 & $-10.67^{*}$ & 4.18 & 0.011 & $-11.53^{* *}$ & 4.24 & 0.006 \\
\hline MOCKTH2O & $13.22^{* * *}$ & 3.49 & $<0.001$ & $14.33^{* * *}$ & 3.71 & $<0.001$ \\
\hline MOCKTH30 & 9.56 & 5.40 & 0.077 & $14.33^{*}$ & 6.20 & 0.021 \\
\hline MOCKTH40 & 3.60 & 3.31 & 0.277 & 2.46 & 3.51 & 0.483 \\
\hline MOCKTH50 & -2.49 & 2.73 & 0.363 & -3.30 & 2.83 & 0.243 \\
\hline MOCKTH6O & -7.94 & 4.41 & 0.072 & -7.61 & 4.33 & 0.079 \\
\hline MOCKTH70 & $8.89^{*}$ & 4.38 & 0.042 & $9.22 *$ & 4.36 & 0.034 \\
\hline MOCKTH80 & 0.89 & 4.85 & 0.854 & 1.14 & 4.85 & 0.814 \\
\hline MOCKTH9O & 0.21 & 4.95 & 0.966 & 0.50 & 4.93 & 0.919 \\
\hline \multicolumn{7}{|c|}{ Consideration Structure } \\
\hline CONCASH & 3.80 & 4.67 & 0.416 & 4.30 & 4.86 & 0.376 \\
\hline CONSTOCK & $27.2^{* *}$ & 10.46 & 0.009 & $27.96^{* *}$ & 10.56 & 0.008 \\
\hline \multicolumn{7}{|l|}{ Deal Attitude } \\
\hline ATTHOST & $-57.2^{*}$ & 23.78 & 0.016 & $-56.17^{*}$ & 23.32 & 0.016 \\
\hline ATTNEUT & $-26.72^{* * *}$ & 5.19 & $<0.001$ & $-27.37^{* * *}$ & 5.41 & $<0.001$ \\
\hline \multicolumn{7}{|l|}{ Deal Value } \\
\hline In_DEAVAL & $-3.12^{*}$ & 1.27 & 0.014 & $-3.18^{*}$ & 1.26 & 0.012 \\
\hline (Intercept) & $112.85^{* * *}$ & 14.47 & $<0.001$ & $112.9^{* * *}$ & 13.66 & $<0.001$ \\
\hline Industry & $\sqrt{ }$ & & & $\sqrt{ }$ & & \\
\hline Timing & $\sqrt{ }$ & & & $\sqrt{ }$ & & \\
\hline Observations & & & 11,244 & & & 11,244 \\
\hline $\mathrm{R}^{2} / \mathrm{R}^{2}$ adjusted & & & $4 / 0.039$ & & & 0.044 / 0.039 \\
\hline
\end{tabular}


The exceeding of an MBR has a significantly negative impact on the acquisition premium in comparison to those transactions, where no threshold was exceeded. These transactions are priced on average 25.02 percentage points lower. This is probably due to the fact that investors are very cautious about pricing because of the MBR. Thus, through the existence of the MBR, all shareholders get the opportunity to participate in the transaction, but the prices are significantly lower than in transactions without MBR.

The coefficients and significances of the variables EXPOST, MULTITH and of the MINTH variables can only be interpreted very cautiously. They are likely to be largely due to the fact that the effects of different legislations are reflected by them. In general, it can be stated that in countries with an ex-post approach and countries with several thresholds, the takeover premiums are lower - which is then also expressed in the minimum thresholds. However, these variables can be better interpreted in Model 2 by combining them with the EXCEEDTH variable. Thus, when the threshold is exceeded in countries with an ex-post approach, the takeover premiums are 4.49 percentage points higher. However, this result is not significant. Significance, on the other hand, is shown by exceeding a minimum threshold value and a threshold value when multiple threshold values are present. In both cases the coefficients are positive, so that exceeding a threshold value in this form reduces the premiums less strongly.

The increase of control reflected by the 'artificial' mock-thresholds show that transactions where the buyer subsequently receives at least $10 \%$ have a negative impact on the premium. This can be due to a purely financial interest, as for instance Pérez-Soba et. al. (2017) argue. The acquirers do not strive to exert any influence on the company by acquiring the shares and therefore pay lower premiums. Acquirers who gain $20 \%$ or more with the transaction are willing to pay the highest premiums. The gain in influence is therefore estimated to be highest at this threshold. This may be due to the fact that these are purchases from acquirers who hold no prior shares in the company. In addition to financial aspects, they aim to gain influence on the company and pay for these additional privileges. Depending on the structure of the target, the acquirer is one of the major shareholders with $20 \%$, which would also explain the relatively high premiums.

The effect of the deal size is significant. If the deal value increases by one percent the takeover premium decreases by $-3,12$ percentage points. The negative relationship between the deal volume and the premium corresponds to the findings of Alexandris et. al (2013). The regression models show significant differences in transaction years, reflecting the well known phenomenon of M\&A-waves (Meier, Boysen-Hogrefe \& Spoida, 2007), significant differences in premiums paid by acquirer industry, and significant premiums received by target industry.

Fig. 2 Premium differences against the year 2013 (left), Premium differences against consumer cyclicals and services as acquirer industry (middle), Premium differences against consumer cyclicals and services as target industry (right)

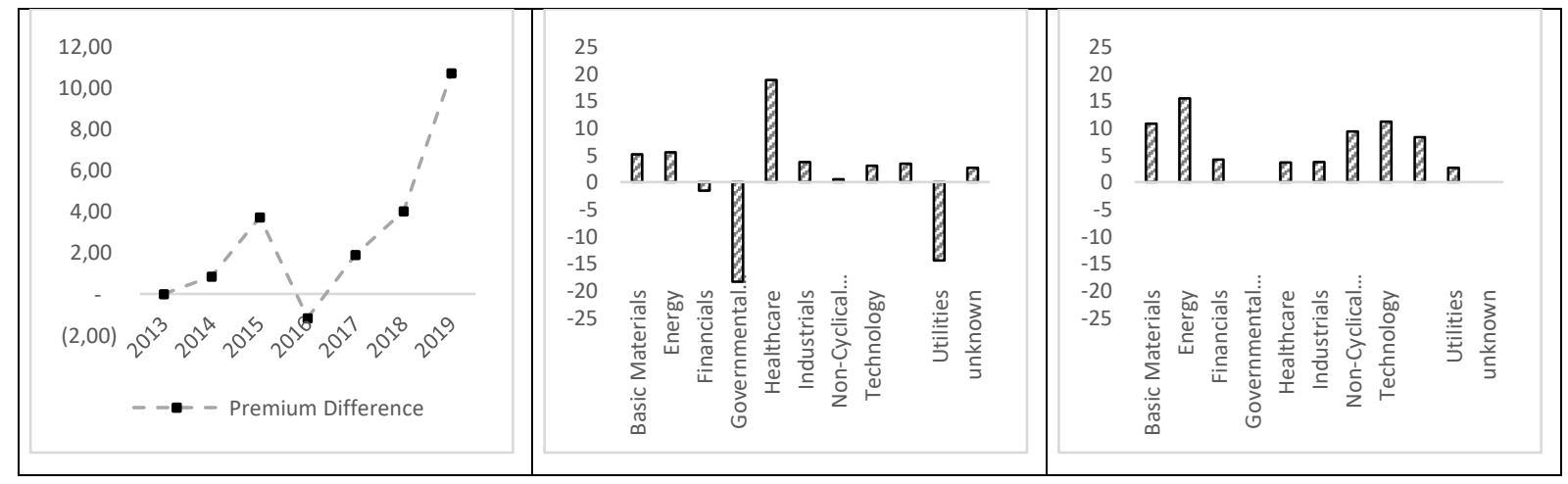




\section{CONCLUSION}

This study examines the influence of a mandatory bid rule on the takeover premium. Exceeding a mandatory bid threshold, which leads to a purchase offer for the shares of the remaining shareholders, has a significant negative impact on the premium. The aspects of an MBR are separated into three variables: dummies for the ex post approach and existence of multiple thresholds, and the levels of the thresholds. All three variables show a significant negative correlation with the acquisition premium. The positive effect of gaining additional control is analyzed in separate variables and shows that acquirers pay significantly more when they own between $20 \%$ and $40 \%$ of the shares after the transactions.

For the M\&A strategy of companies it seem important, that acquisitions are obviously priced very cautiously when the MBR threshold is exceeded. A strategy corresponding to the national minimum price regulation must therefore already be prepared in the medium-term run-up to the exceeding of the threshold or tender offer in order to be able to carry out a cautious pricing.

There are also implications for the European legislator and the national counterparts. The intended protection of the shareholders of the target may work, but significantly lower premiums are paid than would be the case without an MBR. Thus, the question arises, whether the shareholder protection rights gained and the declining takeover premiums set-off each other. This leaves room for future research.

\section{REFERENCES}

Alexandridis, G., Fuller, K. P., Terhaar, L., \& Travlos, N. G. (2013). Deal size, acquisition premia and shareholder gains. Journal of Corporate Finance, 20, 1-13. https://doi.org/10.1016/j.jcorpfin.2012.10.006

Amihud, Y., Lev, B., \& Travlos, N. G. (1990). Corporate Control and the Choice of Investment Financing: The Case of Corporate Acquisitions. The Journal of Finance, 45(1), S. 603-616. https://doi.org/10.2307/2328673

Andrade, G., Mitchell, M., \& Stafford, E. (2001). New evidence and perspectives on mergers. Journal of Economic Perspectives, 15, 103-120. https://doi.org/10.1257/jep.15.2.103

Antoniou, A., Arbour, P., \& Zhao, H. (2008). How Much Is Too Much: Are Merger Premiums Too High?. European Financial Management, 14(2), 268 - 287.

https://doi.org/10.1111/j.1468-036X.2007.00404.X

Bauguess, S. W., Moeller, S. B., Schlingemann, F. P., \& Zutter, C. J. (2009). Ownership structure and target returns. The Journal of Corporate Finance, 15(1), 48-65. https://doi.org/10.1016/j.jcorpfin.2008.09.002

Betton, S., Eckbo, B.E., \& Thorburn, K.S. (2008). Corporate Takeovers. In: Eckbo, B.E. Handbook of Corporate Finance: Empirical Coporate Finance, Vol. 2, 291-430.

Bruner, R. (2002). Does M\&A Pay? A Survey of Evidence for the Decision-Maker. Journal of Applied Finance, 12(1), $48-68$.

Cai, J., \& Vijh, A. M. (2007). Incentive Effects of Stock and Option Holdings of Target and Acquirer CEOs. The Journal of Finance, 62(4), 1891-1933. https://doi.org/10.1111/j.15406261.2007.01260.x

Cakici, N., Hessel, C., \& Tandon, K. (1991). Foreign acquisitions in the United States and the effect on shareholder wealth. Journal of International Financial Management and Accounting, 3(1), 39-60. https://doi.org/10.1016/0378-4266(94)00131-6 
Davidson III, W. N., \& Cheng, L. T. W. (1997). Target Firm Returns: Does the Form of Payment Affect Abnormal Returns?. Journal of Business Finance \& Accounting, 24(3), 465479. https://doi.org/10.1111/1468-5957.00115

Demsetz, H., \& Lehn, K. (1985). The Structure of Corporate Ownership: Causes and Consequences. Journal of Political Economy, 93(6), 1155-1177.

Dutz, M. A. (1989). Horizontal mergers in declining industries: Theory and evidence. Journal of Industrial Organization, 7(1), 11-33. https://doi.org/10.1016/0167-7187(89)90044-1

Dyck, A., \& Zingales, L. (2004). Private Benefits of Control: An International Comparison. The Journal of Finance, 59(2), 537-600. https://doi.org/10.1111/j.1540-6261.2004.00642.x

Eswar, S. K. (2019). Does the Mandatory Bid Rule Add Value to Target Shareholders? Financial Management, 48(3), 739-771. https://doi.org/10.1111/fima.12239

Flanagan, D. J., \& O'Shaughnessy, K. C. (2003). Core-related acquisitions, multiple bidders and tender offer premiums. Journal of Business Research, 56(8), 573-585. https://doi.org/10.1016/S0148-2963(01)00269-7

Franks, J., \& Mayer, C. (1996). Hostile takeovers and the correction of managerial failure. Journal of Financial Economics, 40(1), 163-181. https://doi.org/10.1016/0304405X(95)00840-B

Garfinkel, J. A., \& Hankins, K. W. (2011): The role of risk management in mergers and merger waves. Journal of Financial Economics, 101(3), 515-532. https://doi.org/10.1016/j.jfineco.2011.03.011

Gaspar, J.-M., Massa, M., \& Matos, P. (2005). Shareholder investment horizons and the market for corporate control. Journal of Financial Economics, 76(1), 135-165. https://doi.org/10.1016/j.jfineco.2004.10.002

Ghosh, A., \& Ruland, W. (1998). Managerial Ownership, the Method of Payment for Acquisitions, and Executive Job Retention. The Journal of Finance, 53(2), 785-798. https://doi.org/10.1111/0022-1082.325125

Goel, A. M., \& Thakor, A. V. (2010). Do Envious CEOs Cause Merger Waves?. Review of Financial Studies, 23(2), 487-517.

Goergen, M., \& Renneboog, L. (2004). Shareholder Wealth Effects of European Domestic and Cross-border Takeover Bids. European Financial Management, 10(1), 9-45.

https://doi.org/10.1111/j.1468-036X.2004.00239.x

Grinstein, Y., \& Hribar, P. (2004). CEO compensation and incentives: Evidence from M\&A bonuses. Journal of Financial Economics, 73(1), 119-143.

https://doi.org/10.1016/j.jfineco.2003.06.002Harford, J., \& Li, K. (2007). Decoupling CEO Wealth and Firm Performance: The Case of Acquiring CEOs. Journal of Finance, 62(2), 917949. https://doi.org/10.1111/j.1540-6261.2007.01227.x

Huber, P. J. (1967). The behavior of maximum likelihood estimates under nonstandard conditions. In: Le Cam, L. M.; Neyman, J. (ed.): Proceedings of the Fifth Berkeley Symposium on Mathematical Statistics and Probability. Volume 1: Statistics. Proceedings Fifth Berkeley Symposium on Mathematical Statistics and Probability. Berkeley; University of California Press. S. 221-233.

Jensen, M. C. (1998): Takeovers: Their Causes and Consequences. The Journal of Economic Perspectives, 2(1), 21-48. 
Jensen, M. \& Ruback, R. (1983). The market for corporate control: the scientific evidence. Journal of Financial Economics, 11(1-4), 5 - 50. https://doi.org/10.1016/0304405X(83)90004-1

La Porta, R., Lopez-De-Silanes, F., Shleifer, A., \& Vishny, R. W. (1997). Legal Determinants of External Finance. The Journal of Finance, 52(3), 1131-1150.

https://doi.org/10.1111/j.1540-6261.1997.tb02727.x

La Porta, R., Lopez-de-Silanes, F., Shleifer, A., \& Vishny, R. W. (1998). Law and Finance. Journal of Political Economy, 106(6), 1113-1155. https://doi.org/10.1086/250042

Lambrecht, B. M. (2004). The timing and terms of mergers motivated by economies of scale. Journal of Financial Economics, 72(1), 41-62. https://doi.org/10.1016/j.jfineco.2003.09.002

Levine, R. (2002). Bank-Based or Market-Based Financial Systems: Which Is Better?. Journal of Financial Intermediation, 11(4), 398-428. https://doi.org/10.1006/jfin.2002.0341

Martynova, M. \& Renneboog, L. (2008). A century of corporate takeovers: What have we learned and where do we stand? Journal of Banking \& Finance, 32(10), 2148 - 2177. https://doi.org/10.1016/j.jbankfin.2007.12.038

Meier, J.-H., Boysen-Hogrefe, J., \& Spoida, V. K. (2007). Mergerwellen in Deutschland: Eine zeitreihenanalytische Untersuchung. Arbeitspapier des Instituts für Weltwirtschaft Kiel. Kiel.

Meier, J.-H., Paientko, T.; Meinzer, C. R. (2019). Determinants of Acquisition Premiums in M\&A-Transactions: An Analysis of Deal Characteristics. In: Nadig, L. (ed.): CARF Luzern 2019: Controlling. Accounting. Risiko. Finanzen. Proceedings CARF Luzern. Rotkreuz Verlag IFZ Hochschule Luzern, 235-254.

Mitchell, M. L., \& Mulherin, J. H. (1996). The impact of industry shocks on takeover and restructuring activity. Journal of Financial Economics, 41(2), 193-229. https://doi.org/10.1016/0304-405X(95)00860-H

Moeller, S. B., Schlingemann, F. P., \& Stulz, M. (2004). Firm size and the gains from acquisitions. Journal of Financial Economics, 73(2), 201-228. https://doi.org/10.1016/j.jfineco.2003.07.002

Morck, R., Shleifer, A., \& Vishny, R. W. (1990). Do Managerial Objectives Drive Bad Acquisitions?. The Journal of Finance, 45(1), 31-48. https://doi.org/10.2307/2328808

OECD: Corporate Governance Factbook. 2014.

OECD: Corporate Governance Factbook. 2015.

OECD: Corporate Governance Factbook. 2017.

OECD: Corporate Governance Factbook. 2019.

Ouimet, P. P. (2013). What Motivates Minority Acquisitions? The Trade-Offs between a Partial Equity Stake and Complete Integration. Review of Financial Studies, 26(4), 1021-1047. https://doi.org/10.1093/rfs/hhs125

Ovtchinnikov, A. V. (2010). Capital structure decisions Evidence from deregulated industries. Journal of Financial Economics, 95(2), 249-274. https://doi.org/10.1016/j.jfineco.2009.10.003

Pérez-Soba, I.; Márquez-de-la-Cruz, E.; Martínez-Cañete, A. R. (2018). Further empirical evidence on block transactions below the MBR: the Spanish market. The European Journal of Finance, 24(14), 1244-1251. https://doi.org/10.1080/1351847X.2017.1359197

Rhodes, M., Robinson, D. T., \& Viswanathan, S. (2005). Valuation waves and merger activity: The empirical evidence. Journal of Financial Economics, 77(3), 561-603. https://doi.org/10.1016/j.jfineco.2004.06.015 
Rossi, S., \& Volpin, P. F. (2004). Cross-country determinants of mergers and acquisitions. Journal of Financial Economics, 74(2), 277-304. https://doi.org/10.1016/j.jfineco.2003.10.001

Shleifer, A., \& Vishny, R. W. (2003). Stock market driven acquisitions. Journal of Financial Economics, 70(3), 295-311. https://doi.org/10.1016/S0304-405X(03)00211-3

Stulz, R. M. (1988). Managerial Control of Voting Rights Financing Policies and the Market of Corporate Control. Journal of Financial Economics, 20(1-2), 25-54. https://doi.org/10.1016/0304-405X(88)90039-6

Teece, D. J. (1980). Economies of scope and the scope of the enterprise. Journal of Economic Behavior \& Organization, 1(3), 223-247. https://doi.org/10.1016/0167-2681(80)90002-5

Varaiya, N. P., \& Ferris, K. R. (1987). Overpaying in Corporate Takeovers: The Winner's Curse. Financial Analysts Journal, 43(3), 64-70. https://doi.org/10.2469/faj.v43.n3.64

White, H. (1980). A Heteroskedasticity-Consistent Covariance Matrix Estimator and a Direct Test for Heteroskedasticity. Econometria, 48(4), 817-838. https://doi.org/10.2307/1912934

Williamson, O. E. (1971). The Vertical Integration of Production: Market Failure Considerations. The American Economic Review, 61(2), 112-123.

Williamson, O. E. (1983). Credible Commitments: Using Hostages to Support Exchange. The American Economic Review, 73(4), 519-540.

Williamson, O. E., Wachter, M. L., \& Harris, J. E. (1975). Understanding the Employment Relation: The Analysis of Idiosyncratic Exchange. The Bell Journal of Economics, 6(1), 250278. https://doi.org/10.2307/3003224

Zhu, P., \& Jog, V. M (2009). Information Asymmetry and Acquisition Premiums in Domestic and Cross Border M\&As in Emerging Markets. Working Paper. 2009. ssn.com: 1360318.

Zhu, P., Jog, V., \& Otchere, I. (2011): Partial acquisitions in emerging markets: A test of the strategic market entry and corporate control hypotheses. Journal of Corporate Finance, $17(2)$, 288-305. https://doi.org/10.1016/j.jcorpfin.2010.09.003 